\title{
Rationalization of Fisheries Business Affected by the Covid-19 Pandemic: Case Study: Sungai Batang Village,Province of South Kalimantan, Indonesia
}

\author{
Singgih Honggo Seputro ${ }^{1}$, Idiannor Mahyudin ${ }^{2 *}$, Ahmadi $^{3}$ \\ ${ }^{I}$ Marine and Fisheries Service of South Kalimantan Province \\ ${ }^{2,3}$ Fisheries Science Post Graduate Program, Lambung Mangkurat University, Indonesia \\ *Corresponding Author: Idiannor Mahyudin, Fisheries Science Post Graduate Program, Lambung \\ Mangkurat University, Indonesia

\begin{abstract}
The COVID-19 pandemic has a negative impact on the world's economy including fisheries businesses in Indonesia. A case of study was performed to rationalize fishery business affected by COVID19pandemic in Sungai Batang Village,South Kalimantan Province of Indonesia,started from August 2020 to May 2021. The research aims at analyzing(1) the profit comparison, (2) the perception of purchasing power and (3) rationalization strategy of fishery business affected by Covid-19 pandemic. A total of 64 respondents were selected and deeply interviewed using semi-structured questionnaires. Data were analyzed quantitatively using a range of different equations. The results showed that fishery business profit during the pandemic decreased by $40.86 \%$, while the purchasing power declined by $70.31 \%$.To rationalize fishery business affected by this pandemic, it is strongly recommended (1) controlling fishery commodity production and increasing competitiveness of processed fishery products, (2) managing business cash flow to maintainbusiness operations in a healthy manner through efficiency and effectiveness of production costs coupled with a recovery in the availability of business capital; (3) applyingfor relaxation of credit loan installment payments from banking institutions or other financial institutions; and (4) expanding the marketing channel of fishery commodities and processed fishery products by activating an e-commerce-based buying and selling portal.
\end{abstract}

Keywords: Fishery business, profit,purchasing power,rationalization,Sungai Batang Village.

\section{INTRODUCTION}

Like other countries, the Covid-19 pandemic is also widespread and rapidly reaching Indonesia, requires the government to immediately take policy steps to control its spread. The implementation of the Large-Scale Social Restriction rules resulted in limited space for movement and community activities in the public zone [1]. The Covid-19 outbreak not only created a health emergency but also have the impact on the global economic sector, including marine and fisheries sector. The impact is felt, among others, the price of fish dropped dramatically by $50 \%$ due to reduced market demand due to lack of buyers. Fish distribution has also experienced obstacles due to this policy. During the Covid-19 pandemic,many ecotourism locations were also temporally closed, and the sales of processed fishery products decreased significantly [2].

To control and restore the economic impactof the Covid-19 pandemic, small scale fisheries business need to be assisted in solving this problem through a scientific approach in determining the priority strategies for their business rationalization. By doing this, it is expected that fishery business activities during the COVID-19 pandemic keep going on,and thenthe business profits and purchasing power of fisheries businessmen can be restored.Therefore, the research aimedat analyzing(1) the profit comparison, (2) the perception of purchasing power and (3) rationalization strategy of fishery business affected by Covid-19 pandemic. 


\section{Materials AND Methods}

\subsection{Site Study}

This research was conducted in Sungai Batang Village of South Kalimantan Province, Indonesia,starting from August 2020 to May 2021. Except fishing business activities in the rivers, the villagers also involved in fish farming in fish cages, fish processing and marketing of fisheries products.

\subsection{Research Methods and Data Analysis}

The research activities included comparative analysis of profits and perceptions of the purchasing power of fishery businessmen in Sungai Batang Village before and during the Covid-19 pandemic. Furthermore, SWOT analysis was used to formulate the prioritized strategic plan for rationalizing of fisheries businesses affected by the Covid-19 pandemic. All data and information obtained from the field survey were well-documented accordingly.

\subsection{ComparativeProfit Analysis}

\subsubsection{Profit Concept}

Profits are an indicator of success in economic activity. Its success depends heavily on the ability of the business unit to create cash flow. Profit analysis aims to obtain information about the benefits obtained from a business activity[3]. Gigentika and Wisudo [4] statedthat the profit $(\pi)$ wasdetermined by Total Revenue (TR) and Total Cost (TC). It can be expressed as $\pi=\mathrm{TR}-\mathrm{TC}$. Economic activity is profitable if the $\pi$ value is positive $(\pi>0)$ or indicated by TR $>$ TC. Mohu et al. [5] explained that the total revenue (TR) is the result of multiplication between the amount of production $(\mathrm{Q})$ and the price $(\mathrm{P})$ of each unit of product sold. Total revenue can be calculated using the following equation [6]:

$$
\mathrm{TR}=\mathrm{P} \times \mathrm{Q}
$$

While Total cost (TC) is the sum of fixed cost (FC) and variable cost (VC) spent along business activity, which can be stated with a simple equation[7]:

$$
\mathrm{TC}=\mathrm{FC}+\mathrm{VC}
$$

\subsubsection{Profit Analysis}

The profit analysis uses a qualitative approach with a survey method. Data were analyzedto compare the profits obtained before and during the Covid-19 pandemic. The profit was stated in percentage using the following equation [8]:

$$
g \pi_{t}=\frac{\pi_{t}^{r}-\pi_{t-1}^{r}}{\pi_{t-1}^{r}} \times 100 \%
$$

where: $\mathrm{g} \pi_{\mathrm{t}}=$ profitgrowth $(\%), \pi_{\mathrm{t}}^{\mathrm{r}}=$ profit during the Covid-19 pandemic, $\pi_{\mathrm{t}-1}^{\mathrm{r}}=$ profit before the Covid-19 pandemic.

The next step is to find business feasibility status during the Covid-19 pandemic with R/C Ratio. The Revenue-cost ratio aims to see how much each Rupiah value of cost used in business activities can provide a certain amount of revenue value as a benefit. When $\mathrm{R} / \mathrm{C}>1$ it is considered a profitable business; $\mathrm{R} / \mathrm{C}<1$ meaning business is not feasible; and $\mathrm{R} / \mathrm{C}=1$ meaning busines that are run under conditions of break event point (BEP).R/C ratio can be simply estimated using the following formula[9]:

$$
\text { R/C Ratio }=\text { TR/TC }
$$

\subsection{Purchasing Power Perception Analysis}

\subsubsection{The concept of Purchasing Power}

Purchasing power can be defined as the ability of individuals and organizations to buy and use goods and services. The factors that influence purchasing power are income, taste, and price. Income is 
money that a person receives in the form of wages, rent, interest, or profit. Taste is a person's willingness or desire to consume and use goods or services. Price is the amount of money that is charged to a certain product, the price in sales is very influential on individuals and groups in making purchases [10].

Consumer's income is the main factor determining purchasing power. The pattern of public consumption is determined by the level of income, the higher the people's income, the better the consumption pattern, this is because people can meet the need for consumption. This indicates that income is one of the main elements that support consumer purchasing power [11].According to Yusuf and Nurmalah [12],expenditure per capita describes how much purchasing power people have in consuming goods and services. An increase in income will be followed by an increase in people's purchasing power. Income per capita has a positive effect on purchasing power, the more the income per capita will increase the purchasing power, conversely, the lower the income per capita, the lower the purchasing power will be.

The income variable has a positive and significant effect on the amount of household consumption. Income reflects a person's ability to consume both in quality and quantity. The greater the income obtained, the greater the ability to meet food and non-food needs and vice versa. An increase in income will change the consumption pattern of community members. This is because income levels vary between households according to the level of need and ability to manage them[13].Consumption Theory with the Relative Income Hypothesis put forward by James Duesenberry (1949) explained that consumption expenditure is irreversible. This means that the pattern of a person's expenditure when income increases are different from the pattern of expenditure when income has decreased. Consumption expenditure is divided into two, namely food consumption and non-food consumption. Food consumption consists of grains, vegetables, nuts, fruits, oils and fats, beverage ingredients, spices, processed food, fish, meat, eggs, and milk, while non-food consists of fuel, various goods and services, education costs, health, clothing, footwear, durable goods, and insurance premiums [14].

\subsubsection{Analysis of Public Perceptions}

Public perception survey aims to get answers quickly to a question that is conveyed directly to respondents through face-to-face, filling out a questionnaire paper, or by telephone. Questions are designed in such a way that answers are easy to categorize and quantify[15].The type of questionnaire uses the Likert scale method which is closed. The Likert scale method is generally used to measure the level of attitude through attitude statements regarding the object of the attitude to be disclosed[16].Sources of data for the analysis of purchasing power perceptions were also obtained from questionnaires. The questionnaire was filled in by respondents to the questions posed with 4 answer choices, namely: Decreasing, Increasing, Fixed and Not sure. The percentage of perception based on relative frequency per group of research objects can be calculated using the following formula [17]:

$$
\mathrm{p}=\frac{\mathrm{f}}{\mathrm{n}} \times 100 \%
$$

where: $\mathrm{p}=$ the perception $(\%), \mathrm{f}=$ the frequency of the answers for each of the choices, $\mathrm{n}=$ the total number of respondents.

\subsection{Rationalization Strategy}

\subsubsection{Rationalization Concept}

The rationalization of economic activity is a strategy to change human action following the values of economic rationality, which is guided by the use of the most effective means for achieving better goals creatively and independently, by taking careful account of the means of support [18] .

Rationalization can also be interpreted as a process, way, action to make it rational (according to the ratio), or to make the ratio appropriate (good). In business management, rationalization is one of the policy strategies to improve the situation through saving labor and costs, as well as controlling production, so that the business that is run is healthy[19]. 


\subsubsection{SWOT Analysis}

SWOT analysis is a tool that can be used effectively in determining planning strategies and making decisions to achieve goals. SWOT analysis is carried out by identifying and evaluating the internal and external aspects that are both beneficial and unfavorable to achieve these goals. SWOT compares strengths, weaknesses, opportunities, and threats. Strengths and weaknesses are present and future opportunities and threats. The clearer understanding of strengths and weaknesses, the less likely it is to pursue unfeasible opportunities. Also, decent opportunities can be used to fight threats, weaknesses can be overcome through strengths and strengths that can be used to respond to threats [20].

According to Sudarmo et al. [21], the SWOT analysis procedure was carried out in the following stages: (1) Determining internal (strengths and weaknesses) and external (opportunities and threats) factors, (2) Determining the weight and rating of each internal factor and external factor, (3) Determining the weighted score by multiplying the weight value to the rating, (4) Arranging the IFAS matrix and EFAS matrix, (5) Preparing Cartesian Diagram, and (6) Constructing the TOWS matrix.

\subsection{Characteristics of Respondents}

A total of 64 respondents who have KUSUKA Cards (Fishery business identity card) were deeply interviewed using semi-structured questionnaires. They were 4 fishermen, 39 fish farmers and 21 fish processors and marketers of fishery products as described in Table 1.

Table1. Number of respondents who involved in fisheries business in Sungai Batang Village

\begin{tabular}{|c|l|c|}
\hline No. & The Group of Fishery Businesses & No. Respondents \\
\hline 1. & Inland openwater fishermen & 4 \\
\hline 2. & Freshwater fish farmers & 39 \\
\hline 3. & Fish processors and marketers of fishery products & 21 \\
\hline \multicolumn{2}{|c|}{ Total } & $\mathbf{6 4}$ \\
\hline
\end{tabular}

The age of respondents was ranged of 15-54 year-old. Dewi and Rustariyuni [22] stated that age has a partially positive and significant effect on fishermen's income. While Suroyya et al. [23] added that age was a supporting factor in achieving success in business activities, people who are still productive will be faster in making decisions about business innovations. Most of them were high school graduates $(42.19 \%)$, followed by junior high school (32.81\%), elementary school $(12.50 \%)$, and bachelor's degree (7.81\%). According to Kumaat and Dotulong [24], education can improve the quality of one's ability to carry out business activities. While Sriyono[25] concluded that the level of public education will affect the level of understanding, which will have an impact on the mindset to change a condition that is better than before. Most of them had business experiences of 8-10 years. Ghozali [26] explains that work experience can be said to be the level of mastery of a person's knowledge and skills in a job which can be measured from the length of service and the level of knowledge and skills possessed.

\section{RESULTS AND DiSCUSSION}

\subsection{Profits Analysis}

\subsubsection{Fishermen Profits}

There was change in profit received by local fishermen before and during the Covid-19 pandemic. Table 2 clearly showed that the average profit of fishermen declined by $17.90 \%$ from IDR 141,000/trip to IDR 115,750/trip. The decline in profits of fishermenwas corresponding to the selling prices of catch such as snake-skin gouramy, snakehead fish and other fish decreased from IDR $33,000 / \mathrm{kg}$ to IDR $28,750 / \mathrm{kg}$. This condition is in line with the opinion of Dahar [27] who states that prices have a significant effect on fishermen's income. There is a positive or directional relationship between price variables and fishermen's income. If the price of fish increases, fishermen's income will also increase accordingly. 
Rationalization of Fisheries Business Affected by the Covid-19 Pandemic: Case Study: Sungai Batang Village,Province of South Kalimantan, Indonesia

Table2. Comparative profit of fishermen before and during Covid-19 pandemic

\begin{tabular}{|c|c|c|c|c|}
\hline \multirow{2}{*}{$\begin{array}{c}\text { The Group of Fishery } \\
\text { Business }\end{array}$} & \multirow{2}{*}{$\begin{array}{c}\text { Unit of } \\
\text { Profit }\end{array}$} & $\begin{array}{c}\text { The average profit (IDR) } \\
\text { Pandemic }\end{array}$ & $\begin{array}{c}\text { DuringCovid-19 } \\
\text { Pandemic }\end{array}$ & \multirow{2}{*}{$\begin{array}{c}\text { Profit } \\
\text { Decline(\%) }\end{array}$} \\
\cline { 3 - 4 } & IDR/Trip & 141.000 & 115.750 & 17.90 \\
\hline $\begin{array}{c}\text { Inland open water } \\
\text { fishermen }\end{array}$ & IDRid-19 & & \\
\hline
\end{tabular}

A $17.90 \%$ decline in profits during the Covid-19 pandemic turned out to be still in a favorable condition for local fishermen in Sungai Batang Village with the R/C ratio of 4.61. Neliyana et al. [9] stated that if $\mathrm{R} / \mathrm{C}>1$ meaning that fisheries business was profitableand feasible.

\subsubsection{Fish Farmer Profits}

Like fishermen's profit, the profits received by fish farmers also declined by $58.88 \%$ where before Covid-19 pandemic was IDR 77,058,692/cycle of production decreased to IDR 29,937,236/cycle of production during the Covid-19 pandemic (Table 3). The decline in profits of fish farmers was corresponding to the selling prices of catfish and tilapia from IDR 26,792/kg to IDR 21,382/ $\mathrm{kg}$. In line with this study, Suhardi and Herlina [10]reported that the selling price variable has a significant effect on the income of fish farmers.

Table3. Comparative profit of fish farmers before and during Covid-19 pandemic

\begin{tabular}{|c|c|c|c|c|}
\hline \multirow{2}{*}{$\begin{array}{c}\text { The Group of Fishery } \\
\text { Business }\end{array}$} & Unit of Profit & $\begin{array}{c}\text { The average profit (IDR) } \\
\text { Before Covid-19 } \\
\text { Pandemic }\end{array}$ & $\begin{array}{c}\text { DuringCovid-19 } \\
\text { Pandemic }\end{array}$ & $\begin{array}{c}\text { Profit Decline } \\
\text { (\%) }\end{array}$ \\
\hline Freshwater fish farmer & $\begin{array}{c}\text { IDR/cycle of } \\
\text { production }\end{array}$ & $77,058,692$ & $29,937,236$ & 58.88 \\
\hline
\end{tabular}

Besides reduction of selling prices at the producer level, the decline in profits was also caused by an increase of operating costs for pellet supply due to delays in selling of fish during the Covid-19 pandemic. With this condition, the total cost was born by fish farmers become greater. This implies that the number of operational costs as a variable cost component will affect the total cost that will be disbursed from business activities.

Despite the profits decline by $58.88 \%$, the culture business was considered still in a favorable condition for fish farmers since the $\mathrm{R} / \mathrm{C}$ ratio obtained was 1.24 .

\subsubsection{Fish Processors and Marketers Profits}

The average profit of fish processors and marketers of fishery products before Covid-19 pandemic was IDR 964,429/week, while during the Covid-19 pandemic; it was IDR 522,836/week or declined by $45.79 \%$ (Table 4). The selling price of dried fish/salted fish (snake-skin gourami, snakehead fish, Climbing perch)and sales volume of fish products at the producer level decreased by $23.08 \%$ and $42.17 \%$, respectively. Lack of tourists visiting the Lok Baintan floating market was main reason behind this condition.

Table4. Comparative profit of fish processors and marketers of fishery products before and during Covid-19 pandemic

\begin{tabular}{|l|c|c|c|c|}
\hline \multirow{2}{*}{$\begin{array}{c}\text { The Group of Fishery } \\
\text { Business }\end{array}$} & Unit of Profit & \multicolumn{2}{|c|}{ The average profit (IDR) } & Profit Decline \\
\cline { 3 - 5 } & & $\begin{array}{c}\text { Before Covid-19 } \\
\text { Pandemic }\end{array}$ & $\begin{array}{c}\text { DuringCovid-19 } \\
\text { Pandemic }\end{array}$ & \begin{tabular}{c} 
Pandem \\
\hline $\begin{array}{l}\text { Fish processors and } \\
\text { marketers of fishery } \\
\text { products }\end{array}$
\end{tabular} \\
IDR/week & 964.429 & 522.836 & 45.79 \\
\hline
\end{tabular}

Not with standing decline in profits of fish processors and marketers of fishery products, their fishery businesses were considered still in a favorable condition with $\mathrm{R} / \mathrm{C}$ ratio of 1.35.

\subsection{Perception of Purchasing Power}

Table 5 itemizes the overall perception on purchasing power of fisheries businessmen during the Covid-19 pandemic. About $70 \%$ of respondents agreed that their fisheries business profits declined 
and the rest of $30 \%$ stated in the fixed position. There is a strong correlation between decline in profits and purchasing power. The more income received by the people the more purchasing power to meet their needs. Income conditions will change the consumption pattern of community members. This is because income levels vary between households depend on the level of needs and ability to manage them[11-13].

Table5. Perception analysis of purchasing power of fisheries businessmen during the Covid-19 pandemic

\begin{tabular}{|l|c|c|c|c|}
\hline \multirow{2}{*}{ The Group of Fishery Businesses } & \multicolumn{4}{|c|}{ Percentage of Respondent Perception } \\
\cline { 2 - 5 } & Decreasing & Increasing & Fixed & Not sure \\
\hline Inland openwater fishermen (4) & 25 & 0 & 75 & 0 \\
\hline Freshwater fish farmers (39) & 82 & 0 & 18 & 0 \\
\hline $\begin{array}{l}\text { Fish processors and marketers of } \\
\text { fishery products (21) }\end{array}$ & 57 & 0 & 43 & 0 \\
\hline Overall Perception (64) & 70 & 0 & 30 & 0 \\
\hline
\end{tabular}

\subsection{Rationalization Strategies for the Impacted Fisheries Business}

Inventory of strategic issues being faced by fisheries business men during the Covid-19 pandemic was made based on the result of field observations with the function approach of the $\operatorname{profit}(\pi=\mathrm{TR}-\mathrm{TC})$ in view of Price Stabilization (P); Production Stabilization (Q); Fixed Cost Management (FC); and Operational Cost Management (VC).Then, internal and external factors are classified based on the variables observed (Table 6).

1) Price Stabilization $(\mathrm{P})$

a. Fishery businessmen have no power to determine the selling price of fish (P1).

b. There is a government appeal to buy fishery products (P2).

c. Not yet developed an online-based marketing distribution system (P3).

d. Public interest in consuming fish and processed products (P4).

e. The reduced purchasing power of consumers and collecting agents (P5).

2) Production Stabilization (Q)

a. Availability of productive and experienced fisheries workforce (Q1).

b. Availability of fishery production volume (Q2).

c. Management of fishery production diversification is still not optimal (Q3).

d. The fishery technology used in general is still traditional (Q4).

3) Fixed Cost Management (FC)

a. There is a loan installment expense at the bank that must be paid (FC1).

b. There is no economic stimulus program from the local government to recover fisheries businesses affected by Covid-19 pandemic (FC2).

c. Maintenance costs and labor costs are incurred as fixed costs (FC3).

d. There is assistance from the central government (FC4).

4) Variable Cost Management (VC)

a. Relatively larger operating costs (VC1).

b. There is a role from non-government to assist (VC2). 
Rationalization of Fisheries Business Affected by the Covid-19 Pandemic: Case Study: Sungai Batang Village,Province of South Kalimantan, Indonesia

Table6. Inventory of internal factors and external factors based on the variables observed

\begin{tabular}{|c|c|c|c|}
\hline \multicolumn{3}{|r|}{ SWOT Inventory } & Code \\
\hline \multirow{11}{*}{ 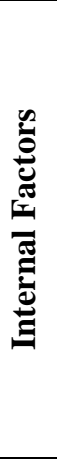 } & \multicolumn{3}{|c|}{ Strengths $(\mathbf{S})$} \\
\hline & S1 & Availability of productive and experienced fisheries workforce & (Q1) \\
\hline & $\mathrm{S} 2$ & Availability of fishery production volume & $(\mathrm{Q} 2)$ \\
\hline & \multicolumn{3}{|c|}{ Weaknesses (W) } \\
\hline & W1 & Fishery business actors have no power to determine the selling price & $(\mathrm{P} 1)$ \\
\hline & W2 & Not yet developed an online-based marketing distribution system & (P3) \\
\hline & W3 & Management of fishery production diversification is still not optimal & (Q3) \\
\hline & W4 & The fishery technology used in general is still traditional & $(\mathrm{Q} 4)$ \\
\hline & W5 & There is a loan installment expense at the bank that must be paid & (FC1) \\
\hline & W6 & Maintenance costs and labor costs are incurred as fixed costs & (FC3) \\
\hline & W7 & Relatively larger operating costs & $(\mathrm{VC} 1)$ \\
\hline \multirow{8}{*}{ 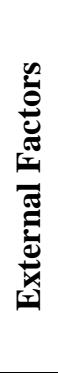 } & \multicolumn{3}{|c|}{ Opportunities (O) } \\
\hline & $\mathrm{O} 1$ & There is a government appeal to buy fishery products & $(\mathrm{P} 2)$ \\
\hline & $\mathrm{O} 2$ & Public interest in consuming fish and processed products & $(\mathrm{P} 4)$ \\
\hline & $\mathrm{O} 3$ & There is assistance from the central government & (FC4) \\
\hline & $\mathrm{O} 4$ & There is a role from non-government to assist & $(\mathrm{VC} 2)$ \\
\hline & \multicolumn{3}{|c|}{ Threats (T) } \\
\hline & $\mathrm{T} 1$ & The reduced purchasing power of consumers and collecting agents & (P5) \\
\hline & $\mathrm{T} 2$ & $\begin{array}{l}\text { There is no economic stimulus program from the local government to recover } \\
\text { fisheries businesses affected by Covid- } 19 \text { pandemic }\end{array}$ & $(\mathrm{FC} 2)$ \\
\hline
\end{tabular}

Internal and external factors were derived from the questionnaire results and interview. While the IFAS (Internal Factor Analysis Strategic) and EFAS (External Factor Analysis Strategic) matrixes were made based on the respondent's perception scale (Table 7).

Table7. IFAS and EFASmatrixes analysis

\begin{tabular}{|c|c|c|c|c|c|}
\hline \multicolumn{3}{|c|}{ IFAS } & Weight & Rating & Score \\
\hline \multicolumn{6}{|c|}{ Strengths (S) } \\
\hline $\mathrm{S} 1$ & $\begin{array}{l}\text { Availability of productive and experienced fisheries } \\
\text { workforce }\end{array}$ & (Q1) & 0,10 & 2,96 & 0,31 \\
\hline $\mathrm{S} 2$ & Availability of fishery production volume & $(\mathrm{Q} 2)$ & 0,11 & 3,00 & 0,33 \\
\hline \multicolumn{3}{|c|}{ Sub Total (S) } & $\mathbf{0 , 2 2}$ & & 0,64 \\
\hline \multicolumn{3}{|c|}{ Weaknesses (W) } & & & \\
\hline W1 & $\begin{array}{l}\text { Fishery business actors have no power to determine the } \\
\text { selling price }\end{array}$ & (P1) & 0,10 & 4,02 & 0,41 \\
\hline $\mathrm{W} 2$ & $\begin{array}{l}\text { Not yet developed an online-based marketing } \\
\text { distribution system }\end{array}$ & (P3) & 0,12 & 3,96 & 0,48 \\
\hline W3 & $\begin{array}{l}\text { Management of ishery production diversification is still } \\
\text { not optimal }\end{array}$ & $(\mathrm{Q} 3)$ & 0,10 & 4,04 & 0,42 \\
\hline W4 & $\begin{array}{l}\text { The fishery technology used in general is still } \\
\text { traditional }\end{array}$ & $(\mathrm{Q} 4)$ & 0,10 & 4,11 & 0,41 \\
\hline W5 & $\begin{array}{l}\text { There is a loan installment expense at the bank that } \\
\text { must be paid }\end{array}$ & (FC1) & 0,12 & 4,13 & 0,50 \\
\hline W6 & $\begin{array}{l}\text { Maintenance costs and labor costs are incurred as fixed } \\
\text { costs }\end{array}$ & (FC3) & 0,10 & 4,30 & 0,45 \\
\hline W7 & Relatively larger operating costs & $(\mathrm{VC} 1)$ & 0,13 & 4,43 & 0,58 \\
\hline \multicolumn{3}{|c|}{ Sub Total (W) } & $\mathbf{0 , 7 8}$ & & 3,25 \\
\hline \multicolumn{3}{|c|}{ Total IFAS } & $\mathbf{1 , 0 0}$ & & 3,90 \\
\hline \multicolumn{3}{|c|}{ EFAS } & Weight & Rating & Score \\
\hline \multicolumn{3}{|c|}{ Opportunities (O) } & & & \\
\hline $\mathrm{O} 1$ & There is a government appeal to buy fishery products & $(\mathrm{P} 2)$ & 0,12 & 4,09 & 0,50 \\
\hline $\mathrm{O} 2$ & $\begin{array}{l}\text { Public interest in consuming fish and processed } \\
\text { products }\end{array}$ & (P4) & 0,19 & 4,14 & 0,77 \\
\hline $\mathrm{O} 3$ & There is assistance from the central government & $(\mathrm{FC} 4)$ & 0,20 & 4,07 & 0,81 \\
\hline $\mathrm{O} 4$ & There is a role from non-government to assist & $(\mathrm{VC} 2)$ & 0,12 & 4,00 & 0,49 \\
\hline \multicolumn{3}{|c|}{ Sub Total $(\mathbf{O})$} & $\mathbf{0 , 6 3}$ & & 2,57 \\
\hline
\end{tabular}


Rationalization of Fisheries Business Affected by the Covid-19 Pandemic: Case Study: Sungai Batang Village,Province of South Kalimantan, Indonesia

\begin{tabular}{|c|l|r|r|r|r|}
\hline \multicolumn{2}{|l|}{ Threats (T) } & & & \\
\hline T1 & $\begin{array}{l}\text { The reduced purchasing power of consumers and } \\
\text { collecting agents }\end{array}$ & (P5) & 0,18 & 4,23 & 0,77 \\
\hline T2 & $\begin{array}{l}\text { There is no economic stimulus program from the } \\
\text { local government to recover fisheries businesses } \\
\text { affected by Covid-19 pandemic }\end{array}$ & (FC2) & 0,19 & 4,02 & 0,77 \\
\hline \multicolumn{2}{|r|}{ Sub Total (T) } & $\mathbf{0 , 3 7}$ & & $\mathbf{1 , 5 3}$ \\
\hline
\end{tabular}

Based on the IFAS and EFAS matrix analysis above, it can be seen that the Strength score of 0.64 was lower than the Weakness score of 3.25, with a difference of -2.61 . Meanwhile, the Opportunity score is 2.57 which is greater than the Threat score of 1.53 , with a difference of 1.04 . Thereby, the ordinate points $\mathrm{S}-\mathrm{W}$ and $\mathrm{O}-\mathrm{W}$ in the Cartesian diagramwere fixed at the point of (-2.61: 1.04) as displayed in Figure 1.

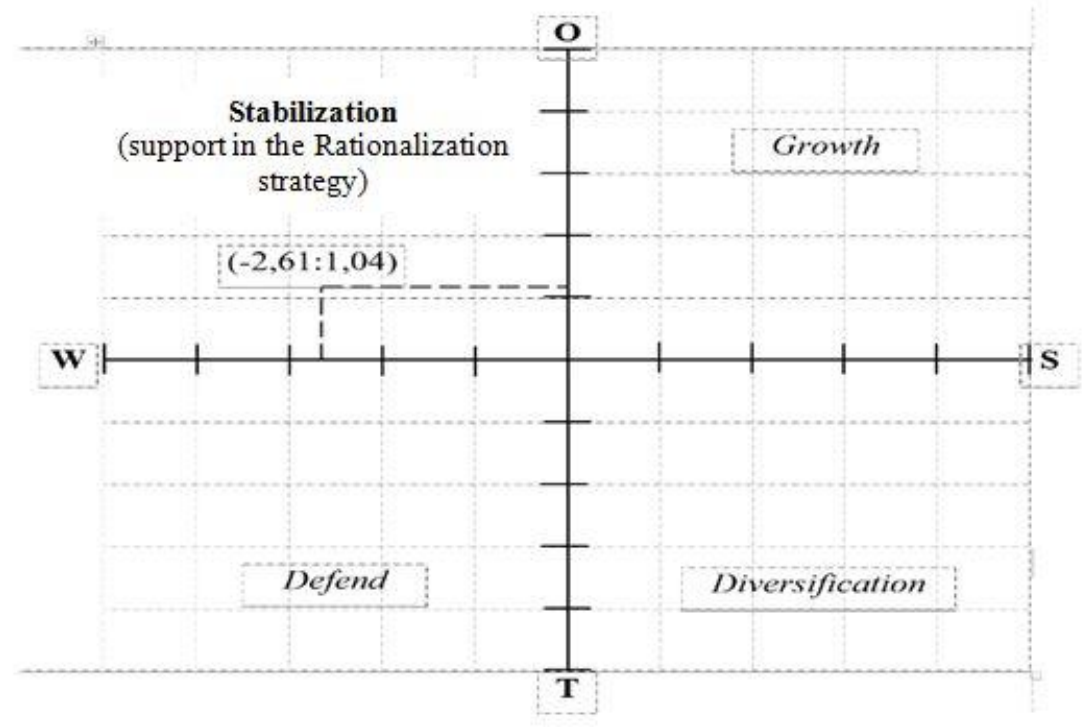

Figure1. Cartesian diagram of IFAS and EFAS analysis results

From the Cartesian Diagram, it can be seen that fishery business activities in Sungai Batang Village substantially have a great opportunity to optimize and maintain business sustainability during the Covid-19 pandemic, even though in point of fact that the weaknesses are still greater than the existing opportunities. In other words, fisheries business can be rationalized by fostering the existing opportunities, while minimizing the internal weaknesses.

To operationalize the ideal concept of fisheries business impacted by the Covid-19 pandemic, further analysis with TOWS Matrix was done by cross-analyzing the identified internal and external factors through the existing IFAS and EFAS matrixes as Sudarmo et al.[21] did. A strategy combination can be set as follows: (1) SO (Strengths-Opportunities) strategy - creating a strategy that uses strength to take advantage of opportunities to support aggressive growth policies;(2) WO (WeaknessesOpportunities) strategy -making a strategy that minimizes weaknesses to exploit and seize better opportunities to maintain business sustainability; (3) ST (Strengths-Threats) strategy -creating a strategy that uses strength to overcome threats through diversification in both product and marketing aspects; and (4) WT (Weaknesses-Threats) strategy -this strategy is based on defensive activities and is aimed at minimizing existing weaknesses and avoiding threats.

Based on the TOWS matrix, there are 4 rationalization strategies to be done to maintain the sustainability of fisheries businesses affected by Covid-19 in Sungai Batang Village, namely:

SO Strategy: Utilizing the potential of human resources and maintaining the continuity of fishery productsavailability, which is directed to supporting aggressive business growth, through the following efforts: 
a. Strengthening the marketing partnership network for fishery products with government agencies and the private sector.

b. Increase the quality and availability of commodities and processed fishery products to maintain consumer loyalty.

c. Empowerment of group institutional functions and roles to obtain assistance programs from the central government.

d. Strengthening business partnership networks with non-governmental capital assistance institutions/agencies.

WO Strategy: Revitalizing the upstream-downstream fisheries business system, which is directed to supporting business stabilization and sustainability during a pandemic, through the following efforts:

a. Controlling fishery commodity production and increasing the competitiveness of processed fishery products.

b. Managing business cash flow to maintain business operations in a healthy manner through efficiency and effectiveness of production costs coupled with a recovery in the availability of business capital.

c. Applying for relaxation of credit loan installment payments from banking institutions/ other financial institutions.

d. Expanding the marketing channel of fishery commodities and processed fishery products by activating an e-commerce-based buying and selling portal.

Since the ordinate point in the Cartesian diagram was in the W-O quadrant area (-2.61: 1.04), so that the WO strategy was acceptable for rationalizing of fisheries business impacted by the Covid-19 pandemic.

ST strategy: Increasing creativity, innovation. and human resource initiatives to increase purchasing power and expansion of capital sources, through the following efforts:

a. Development of business diversification in commodities and processed products with a relatively faster return on business capital.

b. Increased cooperation between fishery business groups and fishery extension agents to submit proposals for stimulus assistance from the local government.

WT Strategy: Imposing a fishery business restructuring to save costs and assets, as well as increasing sales returns and declining profits, through the following efforts:

a. Utilizing information technology to improve access to the marketing of commodities and processed fishery products.

b. Appliying the recommended technology to support fisheries business intensification.

c. Improving cooperative relations with related agencies and other cooperatives/small scale entrepreneurship to gain access to business stimulus assistance.

d. Refocusing on maintenance costs, labor, and operational costs.

\section{CONCLuSion}

The profits and the purchasing power of fisheries businessmen in Sungai Batang Village during the Covid-19 pandemic declined by $40.86 \%$ and $70.13 \%$, respectively. The strategies for rationalizing the fisheries business were prioritized on the revitalization of the upstream-downstream fisheries business system including management control of fishery production,management of business cash flow, financial support and expansion of marketing channel.

\section{ACKNOWLEDGEMENT}

Our gratitude goes to the Head of Fisheries Services of Banjar District and other relevant institutions, and also Fisheries businessmen for kindly supporting this research. Author thanks reviewers for significantly improving the contents of manuscript to publishable level. 


\section{REFERENCES}

[1] Livana, Suwoso, R.H., Febrianto, T., Kushindarto, D., Aziz, F. (2020). Indonesian Journal of Nursing and Health Sciences. Indonesian Journal of Nursing and Health Sciences, 1(1): 37-48.

[2] Sari, M.N., Yuliasara, F., Mahmiah, M. (2020). Dampak Virus Corona (Covid-19) terhadap Sektor Kelautan dan Perikanan: A Literature Review. Jurnal Riset Kelautan Tropis. 2(2): 59-66. https://doi.org/ 10.30649/jrkt.v2i2.41

[3] Vahid, N., Reza Dehghanpour, M., Nasirizadeh, H. (2013). Comparison between accounting profit and economic profit and its effect on optimal point of production. European Online Journal of Natural and Social Sciences. Special Issue on Accounting and Management.2(3): 493-499. http://europeanscience.com/eojnss/article/view/443

[4] Gigentika, S., Wisudo, S.H. (2013). Kelayakan Finansial Usaha Perikanan Pancing Tonda di PPP Labuhan Lombok Kabupaten Lombok Timur. Buletin PSP.21(2):137-148.

[5] Mohu, J.I., Salam, A., Baruadi, A.S. (2016). Analisis Finansial Usaha Perikanan Tangkap Pancing Ulur (Hand Line) Pulau Dudepo Kecamatan Anggrek Kabupaten Gorontalo Utara. Jurnal Ilmiah Perikanan Dan Kelautan.4(3): 98-102.

[6] Ukhty, N. (2018). Analisis Keuntungan Pada Industri Rumah Tangga Pengolah Ikan Di Kecamatan Samatiga Kabupaten Aceh Barat. Jurnal Bisnis Dan Kajian Strategi Manajemen,1(2): 128-137. https://doi.org/10.35308/jbkan.v1i2.906

[7] Arham, N.F., Siang, R.D., Piliana, W.O. (2017). Analisis Keuntungan Pengolahan Ikan Asap (Studi Kasus pada Kelompok Khaerunnisa di Keluarahan Anduonohu Kecamatan Poasia Kota Kendari). Journal Sosial Ekonomi Perikanan FPIK UHO.2(4): 254-262.

[8] Chendrawan, T.S. (2017). Sejarah Pertumbuhan Ekonomi. Tirtayasa Ekonomika, 12(1): 123. https://doi.org/10.35448/jte.v12i1.4441

[9] Neliyana, Wiryawan, B., Wiyono, E.S., Nurani, T.W. (2016). Analisis Kelayakan Usaha Perikanan Pulat Cincin di Pelabuhan Perikanan Pantai (PPP) Lampulo Banda Aceh Propinsi Aceh (Analysis Financial Fisheries of Purse Seine in Lampulo Fishing Port Banda Aceh Provinsi Aceh). Marine Fisheries : Journal of Marine Fisheries Technology and Management.5(2): 163-169. https://doi.org/10.29244/jmf.5.2.163-169

[10] Suhardi, A., Herlina. (2010). Pengaruh Daya Beli Masyarakat Terhadap Nilai Penjualan Ikan Lele Di Desa Ganjaran Kecamatan Pagelaran Kabupaten Pringsewu. Jurnal Manajemen dan Keuangan, 1(1):40-47.

[11] Asriani, Budiyanto, Nurdiana, A. (2016). Pengaruh Pendapatan Konsumen Terhadap Konsumsi Ikan Baronang (Siganus canalicalatus) di Kelurahan Kambu Kota Kendari. Sosial Ekonomi Perikanan FPIK UHO.1: 151-158.

[12] Yusuf, A.A., Nurmalah, S. (2016). Pengaruh Pendapatan Perkapita, Investasi, dan Belanja Pemerintah terhadap daya beli masyarakat di Wilayah III Cirebon Tahun 2010-2014. 8(1): 257-270.

[13] Yanti, Z., Murtala. (2019). Pengaruh Pendapatan, Jumlah Anggota Keluarga dan Tingkat Pendidikan terhadap Konsumsi Rumah Tangga di Kecamatan Muara Dua Kota Lhokseumawe. Jurnal Ekonomika Indonesia, 8(2):72-81.

[14] Iskandar. (2017). Pengaruh Pendapatan Terhadap Pola Pengeluaran Rumah Tangga Miskin di Kota Langsa. JurnalSamudra Ekonomika,1(2):127-134.

[15] Dowler, K., Zawilski, V. (2007). Public perceptions of police misconduct and discrimination: Examining the impact of media consumption. Journal of Criminal Justice.35(2): 193-203. https://doi.org/10.1016/ j.jcrimjus.2007.01.006

[16] Joshi, A., Kale, S., Chandel, S., Pal, D. (2015). Likert Scale: Explored and Explained. British Journal of Applied Science and Technology.7(4): 396-403. https://doi.org/10.9734/bjast/2015/14975

[17] Yulandina, A., Antoni, C., Firmanda, A. (2018). Optimalisasi Unsur Live Shoot Dan Motion Graphic Untuk Promosi Digital Lembaga Paud. Journal of Digital Education, Communication, and Arts (Deca), 1(1): 1-19. https://doi.org/10.30871/deca.v1i1.588

[18] Racko, G. (2019). Does Economic Rationalization Decrease or Increase Accounting Professionals' Occupational Values? Journal of Business Ethics, 158(3): 763-777. https://doi.org/10.1007/s10551-017$3729-6$

[19] Situmorang, B., Lestari, E. (2019). Rasionalisasi Konsep Ekonomi Dan Sosial Pada Pasar Modal Tradisional. Journal of Applied Managerial Accounting.3(2): 193-204. https://doi.org/10.30871/ jama.v3i2.1579

[20] Gurel, E., \& Tat, M. (2017). SWOT Analysis: A Theoretical Review. The Journal of International Social Research, 10(51): 994-1006. 
[21] Sudarmo, A.P., Baskoro, M., Wiryawan, B., Wiyono, E.S., Monintja, D.R. (2016). An Internal and External Analysis of Small-Scale Coastal Fisheries Management in Tegal City. Marine Fisheries Journal.7(1): 45-56. https://doi.org/10.29244/jmf.7.1.45-56

[22] Dewi, I., Rustariyuni, S. (2014). Analisis Faktor-faktor yang Mempengaruhi Pendapatan Nelayan Buruh di Sepanjang Muara Sungai Ijo Gading Kabupaten Jembrana. E-Jurnal Ekonomi Pembangunan Universitas Udayana, 3(1): 42-47.

[23] Suroyya, A.N., Triarso, I., Argo, W.B. (2017). Analisis ekonomi rumah tangga nelayan pada alat tangkap Gill net di PPP Morodemak, Kabupaten Demak. Journal of Fisheries Resources Utilization Management and Technology. 6(4): 30-39.

[24] Kumaat, R.J., Dotulong, L.O. (2015). Pengaruh Pendidikan, Pelatihan, dan Inovasi terhadap Kinerja Pegawai Badan Pelaksana Penyuluhan dan Ketahanan Pangan Kota Manado. Jurnal EMBA, 3(3): 331340.

[25] Sriyono. (2015). Pengaruh Tingkat Pendidikan Dan Pemahaman Masyarakat Tentang Ikan Berformalin Terhadap Kesehatan Masyarakat. Jurnal Faktor Exacta.8(1): 79-91.

[26] Ghozali, (2005). (2018). Pengaruh Pengalaman Kerja Terhadap Laham Kabupaten Mahakam Ulu. EJournal Manajemen Universitas Udayana, 6(3): 465-474.

[27] Dahar, D. (2016). Faktor-Faktor Yang Mempengaruhi Pendapatan Nelayan Di Desa Pohuwato Timur Kecamatan Marisa Kabupaten Pohuwato Darmiati. Jurnal Agropolitan, 3(3): 52-61.

Citation: Singgih Honggo Seputro et al." Rationalization of Fisheries Business Affected by the Covid-19 Pandemic: Case Study: Sungai Batang Village,Province of South Kalimantan, Indonesia", International Journal of Innovative Studies in Aquatic Biology and Fisheries (IJISABF), vol. 7, no.2, pp. 1-11, 2021. http://dx.doi.org/10.20431/2454-7670.0702001

Copyright: () 2021 Authors. This is an open-access article distributed under the terms of the Creative Commons Attribution License, which permits unrestricted use, distribution, and reproduction in any medium, provided the original author and source are credited. 